\title{
The influence of Liquidity, Leverage and Profitability Ratio on Financial Distress
}

(On Real Estate and Property Companies Listed in Indonesia Stock Exchange in 2015-2017)

\author{
Fatimah \\ Universitas Jember \\ Bondowoso, Indonesia \\ Fatimah.am@yahoo.com
}

\author{
Akhmad Toha \\ Universitas Jember \\ Jember, Indonesia \\ tohafisip@gmail.com
}

\author{
Aryo Prakoso \\ Universitas Jember \\ Jember, Indonesia \\ aryo.fisip@unej.ac.id
}

\begin{abstract}
ABSTRAK
This study investigates the role of financial ratio in predicting financial distress which has an important role in preventing bankruptcy. This study aims to know the influence of liquidity, leverage, and profitability ratios on financial distress (on property and real estate companies listed 2015-2017 in Indonesia Stock Exchange). 45 companies listed in Indonesia Stock Exchange from 2015 to 2017 were examined by using 135 units of analysis. Prediction model used was logistic regression technique with purposive sampling method. The result there was no influence of liquidity (current ratio) on financial distress. There was a positive influence of leverage (total dept. on total assets) on financial distress. However, there was a negative influence of profitability (net profit margin) on financial distress.
\end{abstract}

Keywords: Financial distress, Liquidity, Leverage, and Profitability

\section{PENDAHULUAN}

Afriyeni (2012) dalam jurnalnya mengatakan bahwa pada tahun 2008 saat terjadi krisis, sebagian besar perusahaan mengalami masalah keuangan (financial distress), antisipasi agar hal ini tidak terulang kembali, maka sangat penting dan disarankan untuk melakukan prediksi financial distress. Pentingnya prediksi financial distress yang dilakukan Afriyeni diperkuat dengan pernyataan Hapsari (2012) bahwa perusahaan yang tidak sanggup membenahi kinerjanya maka akan mengalami kesulitan keuangan seiring dengan berjalannya waktu yang berujung pada kebangkrutan. Financial distress dalam jurnal Hapsari (2012) diartikan sebagai suatu kondisi perusahaan ketika arus kas operasi dikatakan tidak mampu membayar kewajiban lancar seperti beban bunga serta hutang dagang dan perusahaan harus secepatnya melaksanakan langkah perbaikan. Platt dan Platt (2002) meneliti bahwa financial distress merupakan tahap kondisi keuangan yang menurun terjadi tepat sebelum likuidasi atau kebangkrutan. Brigham dan Daves (2003) memperkuat landasan yang dikemukakan Platt dan Platt, financial distress dapat terjadi karena beberapa kesalahan, yaitu ketidaktepatan pengambilan keputusan dan berbagai kelemahan yang saling berkaitan yang dapat memberi dampak secara tidak langsung maupun langsung pada manajemen perusahaan serta upaya pengawasan secara berkala pada kondisi keuangan yang minim pada perusahaan sehingga apa yang digunakan tidak sesuai dengan apa yang dibutuhkan. Oleh karena itu Murni (2018) mengambil kesimpulan bahwa manajemen perusahaan harus segera mengambil tindakan untuk mengatasi masalah financial distress dan mencegah kebangkrutan. Brahmana (2007) memberikan beberapa indikator perusahaan yang terindikasi financial distress yaitu ketika perusahaan memiliki kinerja yang buruk, laba bersih negatif, laba operasi negatif, nilai buku ekuitas negatif, dan perusahaan yang melakukan merger atau penggabungan dua 
perseroan. Nurhidayah dan Fitriyatur (2017) juga memaparkan indikator bagi perusahaan yang memiliki gejala financial distress yaitu degradasi kinerja perusahaan yang dapat dilihat dengan besarnya beban bunga, utang, dan ketidakcukupan modal.

Muflihah (2017) dalam jurnalnya mengatakan bahwa perusahaan dapat diklaim sedang mengalami financial distress apabila selama dua periode secara berturut-turut perusahaan mengalami kerugian. Penelitian ini berlandaskan pendapat Muflihah (2017) yaitu memakai dua periode penelitian. Disisi lain, syarat minimal sampel untuk menjalankan sistem regresi logistik adalah yaitu $\mathrm{N} \geq 104+\mathrm{m}$. $\mathrm{N}$ merupakan jumlah sampel dan $m$ adalah jumlah variabel independen (Green, 1991). Sampel peneliti tidak memenuhi syarat jika hanya meneliti selama dua tahun. Oleh karena itu penelitian ini meneliti selama tiga tahun yaitu sejak 2015 hingga 2017 melalui laporan keuangan perusahaan untuk mendeteksi adanya financial distress agar sistem regresi dapat dijalankan. Website resmi bursa saham Indonesia yaitu www.idx.co.id akan melakukan langkah delisting (dikeluarkannya saham dari Bursa Efek Indonesia) terhadap perusahaan yang mencerminkan tanda-tanda kebangkrutan sesuai dengan peraturan Bursa Efek Jakarta Nomor: I-I Kep-308/BEJ/072004 yaitu bursa dapat menghapus saham tercatat sesuai dengan aturan dan ketentuan yang telah berlaku.

Tabel 1. Perusahaan BEI yang mengalami

\begin{tabular}{cc}
\multicolumn{2}{c}{ delisting } \\
\hline $\begin{array}{c}\text { Tahun } \\
\text { Perusahaan } \\
\text { Delisting }\end{array}$ & $\begin{array}{c}\text { Jumlah } \\
\text { Perusahaan } \\
\text { Delisting }\end{array}$ \\
\hline 2009 & 8 \\
\hline 2010 & 0 \\
\hline 2011 & 5 \\
\hline 2012 & 4 \\
\hline 2013 & 7 \\
\hline 2014 & 1 \\
\hline 2015 & 3 \\
\hline 2016 & 0 \\
\hline 2017 & 8 \\
\hline
\end{tabular}

Sumber: www.sahamok.com (data diolah, 2019)

Tabel 1. menunjukkan data BEI (Bursa Efek Indonesia) menggambarkan peningkatan perusahaan yang mengalami delisting mulai tahun 2009-2017. Tahun 2009 sebanyak 8 perusahaan mengalami delisting. Tahun 2010 tidak terdapat perusahaan yang mengalami delisting. Tahun 2011 sebanyak 5 perusahaan mengalami delisting. Tahun 2012 sebanyak 4 perusahaan mengalami delisting. Tahun 2013 sebanyak 7 perusahaan mengalami delisting. Tahun 2014 sebanyak 1 perusahaan mengalami delisting. Tahun 2015 sebanyak 3 perusahaan mengalami delisting. Tahun 2016 tidak tercantum data. Tahun 2017 sebanyak 8 perusahaan mengalami delisting (www.sahamok.com). Beberapa perusahaan yang mengalami delisting pada perusahaan properti dan real estate (www.sahamok.com) diantaranya adalah Lamicitra Nusantara Tbk (LAMI), Ciputra Properti (CTRP), Ciputra Surya (CTRS), PT Panca Wirasakti Tbk (PWSI), dan PT Surya Inti Permata (SIIP). Hidayat dan Wahyu (2014) dalam jurnalnya mengatakan bahwa perusahaan dapat didelisting oleh BEI atau Bursa Efek Indonesia dikarenakan perusahaan tersebut sedang atau telah mengalami atau berada pada situasi financial distress. Didukung dengan pendapat Rahayu dan Putri (2016) yang mengatakan perusahaan dengan laporan keuangan yang sehat tidak akan bangkrut dan kemudian didelisting. Financial distress atau kesulitan keuangan terjadi sebelum kebangkrutan (bankruptcy).

Peneliti memilih perusahaan properti dan real estate karena menurut Santoso (2005), industri properti dan real estate adalah sektor utama yang memberi sinyal perekonomian suatu negara terjadi perkembangan atau sebaliknya. Sektor properti adalah sektor terpenting karena digunakan sebagai indikator penting untuk menganalisis kesehatan ekonomi suatu negara. Sektor real estate dan properti merupakan salah satu dari sembilan sektor yang terdaftar di Bursa Efek Indonesia. Peneliti mendukung sektor properti dan real estate menjadi fokus pembangunan pemerintah Indonesia karena pada tahun 2015 Asosiasi REI (Real Estate Indonesia) dalam website resminya (www.rei.or.id) memprediksikan bahwa potensi dan prospek investasi properti dan real estate di Indonesia dalam beberapa tahun mendatang akan mengalami peningkatan yang sangat pesat. REI memberikan pernyataan bahwa pertumbuhan bisnis properti di Indonesia 
masih bisa terus mengalami peningkatan. Selain itu, Fransiska, dalam Febrianty (2017) mengatakan bahwa potensi pertumbuhan pada beberapa sektor terutama pada sektor infrastruktur yang cukup besar di Indonesia. Hal tersebut dibuktikan pemerintah dengan melakukan pembangunan infrastruktur yang cukup besar sehingga memberikan perkembangan perekonomian di Indonesia. Hasanah, dalam Febrianty (2017) mengatakan bahwa sektor properti dan real estate yang akan mendapatkan banyak manfaat dengan dibangunnya infrastruktur oleh pemerintah.

Andre dan Taqwa (2014) mengatakan, analisis rasio keuangan dapat digunakan untuk memprediksi kondisi financial distress perusahaan. Hidayat dan Wahyu (2014) menyatakan bahwa salah satu yang dapat berpengaruh terhadap financial distress atau kesulitan keuangan adalah financial ratios atau rasio keuangan, yang dapat dilihat dalam laporan keuangan yang telah diterbitkan oleh perusahaan. Financial ratios atau rasio keuangan dapat dimanfaatkan sebagai prediktor terjadinya financial distress. Menurut Aksoy dan Ugurlu dalam Hidayat dan Wahyu (2014), financial ratios atau rasio keuangan dapat memberikan keterangan terkait kinerja keuangan perusahaan yang sesungguhnya terjadi. Iramani dalam Hidayat dan Wahyu (2014) mengatakan bahwa penelitian tentang kebangkrutan, kegagalan, maupun financial distress pada perusahaan dapat menggunakan indikator kinerja keuangan sebagai prediksi kondisi perusahaan di masa yang akan datang. Rasio keuangan tersebut seperti likuiditas, profitabilitas, leverage, dan arus kas adalah indikator paling penting dan signifikan serta sering dipakai untuk memprediksi financial distress atau kesulitan keuangan perusahaan pada waktu atau periode tertentu. Kasmir (2016) mengatakan pentingnya rasio leverage, likuiditas, dan profitabilitas dalam memprediksi financial distress.

Peneliti memilih rasio profitabilitas, leverage, dan likuiditas karena banyak ketidakkonsistenan hasil prediksi financial distress meskipun menggunakan alat ukur yang sama. Peneliti tidak menggunakan faktor yang sudah jelas dan terbukti berpengaruh pada studi empiris mengenai kondisi financial distress perusahaan. Penelitian terdahulu yang memakai rasio keuangan dalam penelitiannya, tidak memberikan hasil yang sama pada rasio profitabilitas, leverage, dan likuiditas. Hasil penelitian Hidayat dan Wahyu (2014) menyatakan bahwa rasio aktivitas, leverage, dan aktivitas berpengaruh terhadap kesulitan keuangan atau financial distress. Hasil penelitian Muflihah (2017) menyatakan bahwa likuiditas tidak berpengaruh terhadap kesulitan keuangan atau financial distress, tetapi rasio leverage dan profitabilitas berpengaruh terhadap financial distress atau kesulitan keuangan. Hasil penelitian Choirina dan Etna (2015) menyatakan bahwa rasio pasar berpengaruh terhadap financial distress atau kesulitan keuangan. Hasil penelitian Murni (2018) menyatakan bahwa rasio profitabilitas, leverage, dan likuiditas berpengaruh terhadap financial distress atau kesulitan keuangan. Tetapi dalam penelitian Frans (2017) rasio leverage tidak berpengaruh terhadap financial distress. Putri et al. (2014) juga mengatakan bahwa rasio likuiditas dan leverage tidak berpengaruh terhadap financial distress atau kesulitan keuangan. Penelitian Hanifah dan Agus (2013) mengatakan bahwa rasio leverage mempunyai pengaruh terhadap financial distress dan rasio likuiditas dan profitabilitas tidak memiliki pengaruh terhadap financial distress atau kesulitan keuangan.. Ratna dan Marwati (2018) dalam penelitiannya mengatakan bahwa rasio leverage dan profitabilitas tidak berpengaruh terhadap financial distress atau kesulitan keuangan. Vitarianjani (2015) mengatakan bahwa likuiditas berpengaruh terhadap financial distress dan leverage tidak berpengaruh terhadap financial distress atau kesulitan keuangan.. Haq et al. (2013) mengatakan bahwa rasio likuiditas, leverage, dan profitabilitas berpengaruh terhadap financial distress atau kesulitan keuangan.. Hasil studi empiris menunjukkan bahwa masih terdapat ketidakkonsistensian hasil dari faktor yang mempengaruhi kesulitan keuangan atau financial distress yaitu rasio likuiditas, leverage, dan profitabilitas. Adanya perbedaan pendapat mengenai rasio apa yang sebenarnya mempengaruhi financial distress menarik untuk diteliti. Inilah yang menjadi landasan bagi peneliti untuk melakukan penelitian ini. 


\section{TINJAUAN PUSTAKA}

Teori yang mendukung tentang penelitian ini diantaranya;

\section{a. Signalling Theory}

Teori signalling memberikan penjelasan bagaimana sebuah perusahaan memberikan tanda atau sinyal kepada pelaku atau pengguna laporan keuangan. Brigham dan Houston (2001), menyatakan bahwa sinyal merupakan keputusan yang diambil oleh pihak manajemen perusahaan yang kemudian akan memberikan sinyal atau petunjuk bagi para investor terkait bagaimana manajemen dalam perusahaan memandang prospek dan tujuan perusahaan.

\section{b. Kinerja Perusahaan}

Hartono dalam Nariman (2016) mengatakan bahwa pasar akan memberikan petunjuk dan tanda-tanda pada perusahaan yang memiliki kinerja baik. Sinyal tersebut akan memberikan keseluruhan informasi dari setiap tindakan yang telah dilakukan. Informasi yang dimaksud merupakan informasi tentang apa yang telah dilakukan oleh manajemen perusahaan untuk mewujudkan keinginan pemilik atau tujuan perusahaan. Suwardjono dalam Nariman (2016) mengatakan bahwa laporan keuangan adalah output atau keluaran atas informasi kinerja keuangan perusahaan dari manajemen. Fahmi dalam Maith (2013) menyatakan bahwa kinerja perusahaan merupakan kegiatan yang sangat penting. Kinerja keuangan merupakan analisis yang dilakukan dengan tujuan melihat dan menganalisis seberapa jauh perusahaan telah mencapai target yang sesuai dengan aturan keuangan yang telah ditetapkan. Maith (2013) juga memperkuat dengan menambahkan gagasan dari Prastowo, beliau menyebutkan beberapa unsur atau bagian kinerja keuangan pada perusahaan yaitu: Penghasilan bersih sering digunakan perusahaan untuk mengukur kinerja atau sebagai landasan bagi ukuran lainnya.

\section{c. Financial distress}

Ross (2008) menafsirkan bahwa kesulitan keuangan atau financial distress terjadi apabila perusahaan mengalami kondisi penurunan. Financial distress merupakan kondisi pada saat arus kas perusahaan tidak memadai atas kewajiban - kewajibannya (beban bunga dan kreditur). Dalam kondisi ini, perusahaan dipaksa untuk membuat langkah perbaikan. Kesulitan keuangan (financial distress) jangka pendek bukan suatu keadaan yang parah. Tetapi apabila kesulitan keuangan ini tidak segera ditangani, maka akan berkembang menjadi kesulitan yang fatal sehingga tidak ditemukan penyelesaian atas masalah ini kecuali likuidasi (Hanafi dan Halim, 2014).

Ginting (2017), mengatakan bahwa terdapat terdapat definisi financial distress berdasarkan tipenya, yaitu: kegagalan ekonomi atau economic failure merupakan kondisi pendapatan perusahaan tidak dapat menutup total biaya termasuk cost of capital, kegagalan bisnis atau business failure merupakan keadaan dimana perusahaan menghentikan operasi dengan dalih mengalami kerugian, kebangkrutan teknis atau technical insolvency yaitu perusahaan tidak mampu membayar utang lancarnya bahkan ketika jatuh tempo, kebangkrutan legal atau legal bankruptcy yaitu ketika perusahaan mengajukan tuntutan resmi karena mengalami kebangkrutan, bangkrut dalam kebangkrutan yaitu ketika nilai buku utang perusahaan melebihi nilai pasar pada saat ini (Fachrudin, 2008). Pemicu financial distress menurut Damodaran (2007) adalah kerugian dalam aktivitas operasional dalam perusahaan selama periode tertentu, kesulitan arus kas, dan besarnya jumlah utang. Didukung dengan penelitian Muflihah (2017) bahwa kesulitan arus kas terjadi ketika beban yang dikeluarkan lebih besar daripada pendapatan dari operasional yang diperoleh dan penyimpangan manajemen dalam mengatur dan mengendalikan arus kas yang ada sehingga memperburuk keadaan. Muflihah juga menambahkan besarnya jumlah utang terjadi pada kondisi tagihan yang telah jatuh tempo dan pada saat yang sama perusahaan tidak mempunyai uang atau kas untuk melunasi yang menyebabkan kreditur melakukan penyitaan guna membayar atau melunasi hutang tersebut.

\section{d. Rasio Keuangan}

James C van Horne dalam Kasmir (2015) rasio keuangan adalah indeks atau rata-rata yang menghubungkan antara dua angka dalam 
akuntansi dan dapat diperoleh dengan melakukan pembagian antara satu angka dengan angka lainnya. Nasser dan Aryati dalam Hapsari (2012) mengatakan bahwa rasio keuangan memiliki manfaat dalam memprediksi kebangkrutan dalam suatu perusahaan untuk periode satu sampai dengan lima tahun sebelum perusahaan tersebut benar-benar bangkrut. Jenisjenis Rasio Keuangan menurut Menutut Kasmir (2011) adalah:

\section{1) Rasio Likuiditas}

Rasio likuiditas merupakan rasio yang mengilustrasikan bagaimana kemampuan perusahaan dalam memenuhi hutang atau kewajiban jangka pendeknya. Ketika telah jatuh tempo atau sebelum jatuh tempo, perusahaan mampu membayar kewajibannya. Rasio likuiditas terdiri dari: rasio lancar atau current ratio, rasio cepat atau quick ratio dan rasio kas atau cash ratio (Kasmir, 2011). Rasio yang digunakan dalam penelitian ini adalah current ratio. Alasan digunakannya rasio ini karena apabila kewajiban lancar meningkat lebih cepat dari aktiva lancar, maka rasio lancar akan menurun, kejadian ini memandakan bahwa terdapat masalah dalam perusahaan. Siska (2014) berpendapat, perusahaan dapat dikatakan dalam keadaan likuid apabila perusahaan tersebut mampu memenuhi kewajibannya. Perusahaan dapat dikatakan dalam keadaan illikuid apabila perusahaan tersebut tidak mampu memenuhi kewajibannya.

\section{2) Rasio Solvabilitas (Leverage)}

Rasio solvabilitas atau leverage ratio adalah rasio yang mengukur sejauhmana harta perusahaan dibiayai dengan utang. Rasio solvabilitas antara lain: rasio utang (debt ratio), total hutang terhadap modal (total debt to equity ratio), total hutang terhadap aktiva (total dept to total assets ratio), long term dept to equity ratio, dan time interest earned ratio (Kasmir, 2011). Setiap hutang yang digunakan oleh erusahaan maka akan berpengaruh terhadap risiko dan pengembalian. Rasio yang digunakan dalam penelitian ini debt to asset ratio atau yang disebut debt ratio dan hutang lancar dibagi total aktiva. Alasan digunakannya rasio ini karena apabila semakin kecil rasio ini maka kondisi keuangan perusahaan akan semakin solvable atau aman. Siska (2014) berpendapat, rasio leverage atau solvabilitas sebagai alat ukur sejauh mana aktiva perusahaan dibiayai oleh utang, baik jangka panjang maupun jangka pendek. Hal ini bertujuan agar beberapa hal berkaitan dengan penggunaan modal sendiri dan modal pinjaman dapat diketahui apakah sesuai dengan kebijakan dan tujuan perusahaan atau tidak.

\section{3) Rasio Profitabilitas}

Rasio Profitabilitas adalah kemampuan perusahaan dalam mencari keuntungan yang merupakan ukuran tingkat efektivitas suatu entitas. Kasmir (2016) menambahkan, rasio profitabilitas adalah rasio yang digunakan dan dimanfaatkan perusahaan untuk mencari keuntungan dengan menilai kemampuan perusahaan. Tolak ukur bagaimana suatu perusahaan dapat bertahan dalam bisnisnya dengan memperhatikan tingkat profitabilitas yang konsisten yaitu memperoleh laba (return) yang memadai dibandingkan dengan risiko yang mungkin terjadi. Sehingga semakin tinggi laba yang diperoleh maka kemungkinan perusahaan akan mengalami financial distress semakin kecil. Beberapa jenis rasio ini antara lain: margin laba kotor atau gross profit margin, net profit margin atau margin laba bersih, hasil pengembalian investasi (return on investment/ROI), dan return on equity atau ROE (Kasmir, 2011). Rasio profitabilitas yang digunakan dalam penelitian ini profit margin. Alasan digunakannya rasio ini karena apabila semakin tinggi atau meningkatnya profit margin, maka menandakan semakin baik operasi suatu perusahaan. Siska (2014) mengutip penelitian Kasmir yang mengatakan bahwa rasio profitabilitas memiliki tujuan bagi perusahaan maupun bagi pihak luar perusahaan, yaitu: perhitungan laba yang dihasilkan perusahaan dalam periode tertentu dapat diketahui, agar dapat menilai posisi laba perusahaan tahun tahun sekarang dengan tahun sebelumnya, agar dapat diketahui sejauh mana perkembangan laba perperiode, baik kenaikan atau penurunan serta dapat mencari dan menyelesaikan penyebab perubahan tersebut, sebagai alat ukur produktivitas perusahaan apakah seluruh dana yang digunakan berasal dari modal sendiri maupun pinjaman. 


\section{4) Rasio Aktivitas}

Kasmir (2012) berpendapat, rasio aktivitas adalah banyaknya aktivitas (sumber daya yang digunakan perusahaan untuk mengukur efektivitas perusahaan dalam penggunaan aset atau aktiva yang dimiliki). Menurut Maith (2013), Beberapa jenis rasio ini antara lain: perputaran total aktiva, perputaran aktiva tetap, perputaran persediaan, dan rata-rata umur piutang (Kasmir, 2011). Rasio aktivitas merupakan rasio keuangan yang mengukur perusahaan perusahaan, bagaimana perusahaan tersebut mengelola aktivanya secara efektif dan efisien. Rasio ini digunakan atau dipakai untuk melihat tingkat aktiva milik perusahaan yang dikelola dengan efektif (Warsono, 2003). Sejalan dengan pendapat Brigham (2011) yang mengatakan bahwa rasio aktivitas adalah rasio yang dipakai dan digunakan untuk mengukur bagaimana keefektifan perusahaan dalam menggunakan aktivanya dibandingkan dengan penjualan yang digambarkan dalam suatu laporan keuangan.

\section{5) Rasio Pasar}

Hanafi (2009) mengemukakan bahwa rasio pasar merupakan rasio atas perspektif para investor. Rasio pasar mengukur harga pasar relatif terhadap book value atau nilai buku. Menurut Husnan. S dan Pudjiastuti (2006), Beberapa jenis rasio ini antara lain: price to book value dan price earning ratio. Harahap (2004) Rasio pasar adalah rasio yang khusus dan sering digunakan di pasar modal yang mengilustrasikan situasi dan kondisi atau keadaan prestasi perusahaan dipasar modal tersebut. PER atau Price Earning Ratio adalah cara untuk mengukur besarnya investor dalam menilai laba yang dapat dihasilkan oleh perusahaan. Darmadji dan Fakhrudin (2006) berpendapat, Price Earning Ratio (PER) mengilustrasikan seberapa besar apresiasi pasar terhadap kemampuan atau kinerja perusahaan dalam menghasilkan profit atau laba. Ang (1997) dalam bukunya mengatakan bahwa Price Book Value (PBV) adalah rasio pasar yang dipakai dan dimanfaatkan untuk mengukur kinerja harga pasar saham terhadap nilai bukunya (book value). Ratnasari (2003) melanjutkan, semakin besar PBV atau Nilai Price Book Value maka menunjukkan bahwa harga pasar dari saham semakin tinggi pula.

\section{6) Laporan Keuangan}

Harahap (2008) mengatakan bahwa laporan keuangan merupakan sarana informasi yang merangkum aktivitas-aktivitas di dalam perusahaan. Laporan keuangan adalah hal yang sangat penting bagi suatu perusahaan, karena seorang analis mampu menilai keadaan perusahaan dari segi ekonomis dan prestasi yang telah dicapai. Seseorang tidak akan mampu melihat keseluruhan perusahaan dengan melakukan observasi secara langsung kemudian memberikan rangkuman yang detail. Seandainya hal itu dapat dilakukan, ia tidak dapat mengetahui kondisi perusahaan secara intim dan data yang di dapat belum tentu benar dan dapat dipertanggungjawabkan. Oleh karena itu, sarana yang paling penting dalam perusahaan adalah laporan keuangan. Laporan keuangan merupakan media informasi dalam pengambilan keputusan. Dalam perusahaan, laporan keuangan mengilustrasikan posisi keuangan di suatu perusahaan dalam periode tertentu (Harahap, 2013). Perusahaan dapat dikatakan sehat apabila laporan keuangannya bernilai positif, sebaliknya laporan keuangan yang bernilai negatif mengindikasikan bahwa perusahaan tersebut mengalami financial distress. Hery (2012) berpendapat, pada dasarnya laporan keuangan merupakan proses akuntansi yang dimanfaatkan sebagai media untuk mengkomunikasikan aktivitas perusahaan dan data keuangan kepada berbagai pihak yang membutuhkan. Berbagai pihak yang membutuhkan tentang pertumbuhan perusahaan serta posisi keuangan perusahaan pihak internal dan pihak eksternal. Pihak internal yaitu CEO, direktur, manajer, staff atau karyawan, dan pihak eksternal yaitu kreditor, debitor, pemerintah, pemegang saham, serta masyarakat umum.

Kasmir (2015) sependapat dengan Harahap, beliau mengatakan bahwa laporan keuangan merupakan informasi yang mengilustrasikan keadaan keuangan di suatu perusahaan dalam periode tertentu. Suharli mengatakan laporan keuangan yang lengkap dan menyeluruh mempunyai sepuluh komponen utama laporan keuangan. Komponen tersebut asset atau harta, ekuitas, liabilitas atau kewajiban, comprehensive income atau laba komprehensif, expenses atau 
beban, revenues atau pendapatan, invesments by owners atau investasi dari pemilik, losses atau kerugian, distribution to owners atau distribusi kepada pemilik (Suharli, 2009). Hal pertama yang harus dilakukan untuk melihat sehat atau tidaknya suatu perusahaan, dapat dilihat dalam laporan keuangannya. Dapat diketahui perusahaan mengalami financial distress dengan melihat laporan keuangannya.

\section{METODE PENELITIAN}

Rancangan penelitian ini menggunakan metode penelitian kuantitatif, yaitu berupa data sekunder yang berbentuk time series, diukur dalam suatu skala numerik (angka), yang telah dikumpulkan oleh lembaga pengumpul data (www.idx.co.id) dan dipublikasikan kepada masyarakat pengguna data dan pada interval atau deret waktu tertentu (Haryetti, 2010). Alat analisis yang digunakan dalam penelitian ini adalah regresi logistik (logistic regression) dengan menggunakan SPSS versi 22. Populasi dalam penelitian ini adalah perusahaan real estate dan properti yang terdaftar di Bursa Efek Indonesia (BEI) sebanyak 48 perusahaan selama periode 2015-2017. Jumlah perusahaan yang menjadi sampel sesuai dengan kriteria diatas yaitu 45 perusahaan real estate dan properti sehingga total sampel yang diperoleh selama tiga tahun. Metode penelitian ini mengunakan metode time series dimana 45 perusahaan dikali tiga tahun penelitian yaitu 135 observasi. Data penelitian ini adalah data sekunder yang diperoleh dari situs resmi BEI yaitu www.idx.co.id serta dari sumber-sumber lain yang dianggap relevan dengan penelitian ini.

\section{HASIL DAN PEMBAHASAN}

\section{a. Statistik Deskriptif}

Menurut Sugiyono (2012), analisis statistik deskriptif merupakan statistik yang digunakan untuk menganalisis data dengan menggambarkan atau mendeskripsikan data yang terkumpul sebagaimana adanya yang berlaku untuk generalisasi atau umum. Statistik deskriptif juga dapat digunakan untuk memberikan deskripsi data yang dilihat dari tiga aspek, yaitu mean (rata-rata) yang dipakai untuk menafsirkan atau memperkirakan rata- rata populasi dari sampel, standart deviation atau standar deviasi yang digunakan untuk menilai disperse dari sampel dan maksimumminimum yang digukan untuk melihat ilustrasi atau gambaran keseluruhan dari sampel yang telah terkumpul dan memenuhi syarat dijadikan suatu sampel.

Tabel 2. Hasil Statistik Deskriptif

\begin{tabular}{llllll}
\hline $\begin{array}{l}\text { Variabel } \\
\text { Penelitian }\end{array}$ & $N$ & Min & Max & Mean & $\begin{array}{l}\text { Standar } \\
\text { Deviasi }\end{array}$ \\
\hline $\begin{array}{l}\text { Rasio Likuiditas } \\
\left(X_{1}\right)\end{array}$ & 135 & 0,21 & 19,07 & 2,89 & 2,8581 \\
$\begin{array}{l}\text { Rasio Leverage } \\
\left(X_{2}\right)\end{array}$ & 135 & 0,03 & 0,79 & 0,37 & 0,1866 \\
$\begin{array}{l}\text { Rasio } \\
\begin{array}{l}\text { Profitabilitas } \\
\left(X_{3}\right)\end{array}\end{array}$ & 135 & -1 & 2,28 & 0,24 & 0,4517 \\
$\begin{array}{l}\text { Financial } \\
\text { distress (Y) }\end{array}$ & 135 & 0 & 1 & 0,15 & 363 \\
\hline
\end{tabular}

Sumber: (data diolah, 2019)

Tabel 2. menunjukkan statistik deskriptif masing-masing variabel penelitian. Berdasarkan hasil analisis pada Tabel 4.2 dapat diketahui bahwa untuk variabel Rasio Likuiditas menunjukkan nilai rata-rata (mean) sebesar 2,89. Nilai terendah variabel Rasio Likuiditas sebesar 0,21 dan nilai tertinggi 19,07. Rasio Likuiditas terkecil berada pada perusahaan PT Bukit Darmo Properti, sedangkan Rasio Likuiditas terbesar berada pada perusahaan PT Metro Realty. Standar deviasi sebesar 2,8581 menunjukkan bahwa nilai standar deviasi yang mendekati nilai ratarata (mean) dan ukuran penyebaran data yang semakin kecil. Nilai standar deviasi masing-masing variabel penelitian yang cukup kecil menunjukkan tingkat kesalahan data yang cukup kecil dan tidak terlalu beragamnya data yang digunakan. Berdasarkan hasil analisis pada Tabel 4.2 dapat diketahui bahwa untuk variabel Rasio Leverage menunjukkan nilai rata-rata (mean) sebesar 0,37. Nilai terendah variabel Rasio Leverage sebesar 0,03 dan nilai tertinggi 0,79. Rasio Leverage terkecil berada pada perusahaan PT Puradelta Lestari, sedangkan Rasio Leverage terbesar berada pada perusahaan PT Binakarya Jaya Abadi. Standar deviasi sebesar 0,1866 menunjukkan bahwa nilai standar deviasi yang mendekati nilai rata-rata (mean) dan ukuran penyebaran data yang semakin kecil. Nilai standar deviasi masing-masing variabel 
penelitian yang cukup kecil menunjukkan tingkat kesalahan data yang cukup kecil dan tidak terlalu beragamnya data yang digunakan. Berdasarkan hasil analisis pada Tabel 4.2 dapat diketahui bahwa untuk variabel Rasio Profitabilitas menunjukkan nilai rata-rata (mean) sebesar 0,24 . Nilai terendah variabel Rasio Profitabilitas sebesar -1 dan nilai tertinggi 2,28. Rasio Profitabilitas terkecil berada pada perusahaan PT Nirvana Development, sedangkan Rasio Profitabilitas terbesar berada pada perusahaan PT Green Wood Sejahtera. Standar deviasi sebesar 0,4517 menunjukkan bahwa nilai standar deviasi yang mendekati nilai rata-rata (mean) dan ukuran penyebaran data yang semakin kecil. Nilai standar deviasi masing-masing variabel penelitian yang cukup kecil menunjukkan tingkat kesalahan data yang cukup kecil dan tidak terlalu beragamnya data yang digunakan. Berdasarkan hasil analisis pada Tabel 4.2 dapat diketahui bahwa untuk variabel Financial distress menunjukkan nilai rata-rata (mean) sebesar 0,15 . Nilai terendah variabel Financial distress sebesar 0 dan nilai tertinggi 1. Standar deviasi sebesar 0,3637. Hal ini berarti nilai standar deviasi yang mendekati nilai rata-rata (mean) dan ukuran penyebaran data yang semakin kecil. Nilai standar deviasi masing-masing variabel penelitian yang cukup kecil menunjukkan tingkat kesalahan data yang cukup kecil dan tidak terlalu beragamnya data yang digunakan.

\section{b. Uji Hipotesis}

1) Uji Overall Model Fit

Tabel 3. Uji Overall Model Fit

\begin{tabular}{cl}
\hline Model & Nilai -2 Log Likelihood \\
\hline $2 \log$ likelihood(block number $=0)$ & 116,701 \\
$2 \log$ likelihood(block number $=1)$ & 24,607 \\
\hline
\end{tabular}

Sumber: (data diolah, 2019)

Tabel 3. menunjukkan bahwa nilai $2 \log$ Likelihood block number $=0$ ) yaitu sebesar 116,701 . Hal ini bisa dikatakan bahwa model tanpa variabel tidak fit. Setelah dimasukkan variabel maka nilai 2 log likelihood (block number $=1$ ) mengalami penurunun, sehingga 2 log likelihood (block number $=1$ ) menjadi sebesar 24,607. Penurunan nilai berarti bahwa penambahan variabel independen kedalam model dapat memperbaiki model sehingga model dikatakan fit.

\section{Uji Wald}

Tabel 4, Hasil Uji Wald

\begin{tabular}{lcc}
\hline Variabel & Wald & Sig. \\
\hline LIKUID (X1) & 3,357 & 67 \\
LEV (X2) & 5,519 & 0,019 \\
PROFIT (X3) & 16,782 & 0,000 \\
\hline
\end{tabular}

Sumber: (data diolah)

Tabel 4. menunjukkan besar dari pengaruh masing-masing variabel independen terhadap variabel dependen sebagai berikut:

Rasio Likuiditas menunjukkan tidak terdapat pengaruh terhadap Financial distress, karena Rasio Likuiditas signifikansinya sebesar 0,067 > 0,05 dan Wald menunjukkan angka 3,357 lebih besar bila dibandingkan $\mathrm{T}_{\text {tabel }}$ sebesar 1,656. Artinya semakin tinggi Rasio Likuiditas, maka tidak berpengaruh terhadap probabilitas Financial distress (H1 ditolak).

Jumlah Rasio Leverage menunjukkan pengaruh yang signifikan terhadap Financial distress, karena Jumlah Rasio Leverage signifikansinya sebesar $0,019<0,05$ dan Wald menunjukkan angka 5,519 lebih besar bila dibandingkan $\mathrm{T}_{\text {tabel }}$ (lampiran 4) sebesar 1,656. Artinya semakin tinggi Jumlah Rasio Leverage, maka berpengaruh positif terhadap probabilitas Financial distress (H2 diterima).

Rasio Profitabilitas menunjukkan pengaruh yang signifikan terhadap Financial distress, karena Rasio Profitabilitas signifikansinya sebesar $0,000<0,05$ dan Wald menunjukkan angka 16,782 lebih besar bila dibandingkan $\mathrm{T}_{\text {tabel }}$ sebesar 1,656. Artinya semakin tinggi Rasio Profitabilitas, maka berpengaruh negatif terhadap probabilitas Financial distress (H3 diterima). 
3. Uji Nagelkerke R Square

Tabel 5. Hasil Nagelkerke R Square

\begin{tabular}{ccc}
\hline Model & $\begin{array}{c}\text { Nilai Cox and Snell } R \\
\text { Square }\end{array}$ & $\begin{array}{c}\text { Nilai Nagelkerke } R \\
\text { Square }\end{array}$ \\
\hline 1 & 0,494 & 0,854 \\
\hline
\end{tabular}

Sumber: (data diolah, 2019)

Tabel 5. menunjukkan hasi uji Nagelkerke $R$ Square menunjukkan bahwa Nagelkerke $R$ Square adalah 0,854 (85,4\%) dan nilai Cox dan Snell $R$ Square adalah 0,494 (49,4\%). Artinya adalah variabel independen yaitu Rasio Likuiditas, Rasio Leverage, dan Rasio Profitabilitas mampu menjelaskan variasi dari variabel dependen yaitu Financial distress sebesar $85,4 \%$ sedangkan sisanya dijelaskan oleh faktor-faktor lain yang diluar dari variabel-variabel yang diteliti.

\section{Uji Kelayakan Model Regresi}

Tabel 6. Hasil Uji Hosmer and Lemeshow's Goodneess of Fit Test

\begin{tabular}{ll} 
Nilai $\quad$ Hosmer- & Lemeshow Goodness- \\
Model & Of-Fit Test Statistic Signifikansi \\
\hline
\end{tabular}

$10,319 \quad 0,988$

Sumber: (data diolah, 2019)

Tabel 6. menunjukkan hasi uji hosmer and lemeshow test menunjukkan bahwa nilai Hosmer-Lemeshow Goodness-Of-Fit Test Statistic sebesar 1,319 dan signifikan pada 0,988 yang berarti bahwa nilai signifikansinya lebih dari 0,05 sehingga $\mathrm{H}_{0}$ diterima dan model bisa dikatakan fit, serta mampu memprediksi nilai observasinya atau dapat dikatakan model dapat diterima karena cocok dengan data observasinya. Estimasi chi-square ditujukan untuk mengetahui pengaruh dari Rasio Likuiditas, Rasio Leverage, Rasio Profitabilitas terhadap Financial distress.

\section{Uji Multikolinieritas}

Tabel 7. Hasil Uji Multikolinieritas

\begin{tabular}{|c|c|c|c|}
\hline Variabel & $\mathrm{X} 1$ & $\mathrm{X} 2$ & X3 \\
\hline Constant & 1,000 & $-0,695$ & 0,599 \\
\hline $\mathrm{X} 1$ & 1,000 & 0,508 & $-0,254$ \\
\hline$-x 2$ & 0,508 & 1,000 & $-0,653$ \\
\hline $\mathrm{X} 3$ & $-0,254$ & $-0,653$ & 1,000 \\
\hline
\end{tabular}

Sumber: (data diolah, 2019)
Tabel 7. menunjukkan hasil analisis Collinearity Statistics yang dapat dilihat pada tabel tersebut, diketahaui bahwa model tidak terjadi multikolinieritas. Hal tersebut ditandai dengan nilai VIF dari masing-masing variabel kurang dari 0,8 .

\section{6) Model Regresi Logistik yang Terbentuk}

Peneliti berpedoman pada penelitiam Ghozali dalam Hidayat dan Wahyu (2014) Persamaan regresi yang diperoleh dari pengujian tersebut adalah:

$\mathrm{Ln}=-6,613+0,286$ LIKUID +1,008 LEV 21,124 PROFIT

\section{PEMBAHASAN}

\section{a. Pengaruh Rasio Likuiditas terhadap Financial distress}

Kasmir (2014) dalam bukunya mengatakan bahwa likuiditas dapat digunakan sebagai indikator untuk memprediksi terjadinya financial distress. Hasil pengujian statistik dengan menggunakan regresi logistik menunjukkan bahwa Rasio Likuiditas tidak berpengaruh terhadap financial distress dittnjukkan dengan nilai signifikansi sebesar $0,067>0,05$. Artinya semakin tinggi tingkat Rasio Likuiditas yang diperoleh tidak akan berpengaruh terhadap Financial distress (H1 Ditolak). Hal yang mendasari rasio likuiditas tidak berpegaruh terhadap financial distress adalah perbandingan aset yang jauh lebih besar daripada hutangnya. Aset yang besar tidak memungkinkan perusahaan tersebut bangrut. Sebaliknya, aset yang rendah dan lebih kecil terhadap hutangnya akan memungkinkan perusahaan tersebut terkena financial distress atau bahkan bangkrut. Perhitungan current ratio yang dikemukakan oleh Bambang Riyanto dalam Kasmir (2011) mengatakan bahwa apabila perusahaan menetapkan current ratio yang harus dipertahankan adalah $3: 1$ atau $300 \%$, ini berarti bahwa setiap utang lancar sebesar Rp 1,00 harus dijamin dengan aktiva lancar $\mathrm{Rp}$ 3,00 .

\section{b. Pengaruh Rasio Leverage terhadap Financial distress}

Kasmir (2014) dalam bukunya mengatakan bahwa leverage dapat digunakan sebagai indikator untuk memprediksi 
terjadinya financial distress. Hasil pengujian statistik dengan menggunakan regresi logistik menunjukkan bahwa rasio leverage berpengaruh signifikan terhadap financial distress ditunjukkan dengan nilai signifikansi sebesar $0,019<0,05$. Artinya semakin tinggi Rasio Leverage yang diperoleh akan berpengaruh terhadap financial distress (H2 Diterima). Sebuah perusahaan dalam menjalankan aktivitas bisnisnya tidak akan jauh dari hutang, hampir semua perusahaan memiki hutang untuk menjalankan perusahaan agar dapat terus beroperasi atau untuk mengembangkan perusahaannya. Dengan rasio leverage ini setidaknya dapat mendeteksi seberapa besar hutang yang dimiliki perusahaan, jangan sampai hutang yang dimiliki melebihi kemampuan perusahaan dalam membayar. Rasio leverage merupakan rasio yang digunakan untuk mengukur seberapa besar perusahaan dibiayai oleh modal orang lain atau hutang. Maka dapat dikatakan bahwa terdapat pengaruh yang signifikan dari rasio leverage dalam memprediksi financial distress di suatu perusahaan dan juga nilai koefisien regresi positif berarti semakin tinggi rasio leverage, maka suatu perusahaan akan lebih rentan mengalami financial distress. Total aset dan total hutang merupakan hal yang paling mendasar dalam perusahaan hal ini menyebabkan rasio total aset dan total hutang berpengaruh terhadap Financial distress.

\section{c. Pengaruh Rasio Profitabilitas terhadap Financial distress}

Kasmir (2014) dalam bukunya mengatakan bahwa profitabilitas dapat digunakan sebagai indikator untuk memprediksi terjadinya financial distress. Hasil pengujian statistik dengan menggunakan regresi logistik menunjukkan bahwa rasio profitabilitas berpengaruh negatif signifikan terhadap financial distress ditunjukkan dengan nilai signifikansi sebesar $0,000<0,05$. Artinya semakin tinggi rasio profitabilitas yang diperoleh akan berpengaruh terhadap Financial distress (H3 Diterima). Wild (2005) mengatakan bahwa arus laba yang stabil merupakan ukuran yang penting atas kemampuan perusahaan untuk meminjam saat kekurangan kas, hal itu juga merupakan ukuran perusahaan untuk bangkit dari kondisi kesulitan keuangan. Perusahaan dengan profitabilitas tinggi akan mengurangi risiko financial distress. Dengan melakukan standar efektivitas dalam penggunaan aset perusahaan maka akan mengurangi biaya yang dikeluarkan oleh perusahaan, maka perusahaan akan memperoleh penghematan dan akan memiliki kecukupan dana untuk menjalankan usahanya. Dengan adanya kecukupan dana tersebut maka kemungkinan perusahaan mengalami financial distress akan menjadi lebih kecil.

\section{KESIMPULAN DAN SARAN}

\section{Kesimpulan}

Penelitian ini bertujuan untuk menguji pengaruh dari Rasio Likuiditas, Rasio Leverage, Rasio Profitabilitas terhadap Financial distress. Berdasarkan hasil analisis maka dapat disimpulkan bahwa Likuiditas berpengaruh tidak signifikan terhadap kondisi financial distress perusahaan real estate dan properti yang terdaftar di BEI, Leverage berpengaruh positif signifikan terhadap kondisi financial distress perusahaan real estate dan properti yang terdaftar di BEI, sedangkan Profitabilitas berpengaruh negatif signifikan terhadap kondisi financial distress perusahaan real estate dan properti yang terdaftar di BEI.

\section{Keterbatasan dan Saran}

Penelitian ini memiliki keterbatasan pada pengukuran kategori kelompok perusahaan yang mengalami financial distress dan tidak mengalami financial distress hanya didasarkan pada satu ukuran indeks saja yaitu laba negatif. Penelitian ini juga hanya dilakukan pada perusahaan real estate dan properti sehingga tidak ada pembanding dari sektor lain sehingga benarbenar mewakili emiten di BEI. Studi yang akan datang sebaikknya dapat menggunakan rasio keuangan lainnya sebagai penentu kriteria kesulitan keuangan dan melakukan pengujian tidak hanya pada perusahaan real estate dan properti tetapi juga dilakukan pengujian dengan perusahaan lain sehingga ada perbandingan yang lebih baik. 


\section{DAFTAR PUSTAKA}

Afriyeni, E. 2012. Model Prediksi Financial distress. Polibisnis. 4(2).

Andre, Orina. dan Salma Taqwa. 2014. Pengaruh Profitabilitas, Likuiditas, dan Leverage dalam Memprediksi Financial distress. Jurnal Wahana Riset Akuntansi. 2(1).

Badan Pusat Statistik. 2017. Proyeksi Penduduk menurut Provinsi 20102035. Badan Pusat Statistik. https://www.bps.go.id/linkTabelSta tis/view/id/1274. [Diunduh pada 4 Oktober 2018].

Brahmana, R. 2007. Identifying Financial distress Condition in Indonesia Manufacture Industry. Journal of accounting.

Brigham, Eugene dan Houston. 2001. Manajemen Keuangan. Buku 1 Edisi Kedelapan. Jakarta: Erlangga.

Bursa Efek Indonesia. 2004. Keputusan Direksi PT Bursa Efek Jakarta Nomor: Kep-308/Bej/07-2004 Tentang Peraturan Nomor I-I tentang Penghapusan Pencatatan (Delisting) dan Pencatatan Kembali (Relisting) Saham di Bursa http://www.idx.co.id/peraturan/peratur an-pencatatan/ [Diakses pada 5 Oktober 2018].

Choirina, P. M. dan Etna N. A. Y. 2015. Analisis Faktor-Faktor yang Mempengaruhi Probabilitas Financial distress Perbankan Indonesia. Diponegoro Journal of Accounting. 4(2).

Damodaran, Aswath. 2007. Corporate Finance, Theory and Practice, John Wiley dan Sons. USA: Inc.

Darmadji, Tjiptono dan Hendy Fakhruddin. 2006. Pasar Modal di Indonesia, Pendekatan Tanya Jawab. Jakarta: Salemba Empat.

Fachrudin, K. A. 2008. Kesulitan Keuangan Perusahaan dan Personal. Medan: USUPress.

Febrianty dan Wulandari. 2017. Kinerja Keuangan Perusahaan Real estate dan properti di BEI Selama Periode 2012 2016 yang Termasuk di Indeks LQ45
(Studi pada Perusahaan yang Termasuk Pemeringkatan Indeks LQ45 Periode Februari 2017-Juli 2017). Jurnal Manajemen dan Bisnis Sriwijaya. 15(1)

Fitriyah, I. dan Hariyati. Pengaruh Rasio Keuangan terhadap Financial distress pada Perusahaan Real estate dan properti. Jurnal Ilmu Manajemen. 1(3).

Frans, J. P. 2017. Pengaruh Finacial Leverage, Firm Growth, Laba dan Arus Kas terhadap Financial distress. Jurnal Ekonomi. 4(1).

Ginting, M.C. 2017. Pengaruh Current ratio dan Debt to Equity Ratio (DER) Terhadap Financial distress pada Perusahaan Real estate dan properti di Bursa Efek Indonesia. Jurnal Manajemen. 3(2):37-44.

Green, S.B. 1991. How many subjects does it take to do a regression analysis? Multivariate Behavioral Research. 26:499-510.

Hanafi, M. Mamduh dan Abdul Halim. 2014. Analisis Laporan Keuangan. Cetakan Ketiga. Yokyakarta: UPP STIM YKPN.

Hanifah, O. E. dan Agus P. 2013. Pengaruh Struktur Corporate Governance dan Financial Indicators terhadap Kondisi Financial distress. Journal of Accounting. 2(2).

Haq, S., Muhammad Arfan dan Dana Siswar. 2013. Analisis Rasio Keuangan dalam Memprediksi Financial distress (Studi pada Perusahaan yang Terdaftar di Bursa Efek Indonesia). Jurnal Akuntansi. 2(1).

Harahap, S.. 2008. Analisis Kritis atas Laporan Keuangan. Edisi Kedua. Jakarta: PT. Raja Grafindo Persada.

Haryetti. 2010. Analisis Financial distress untuk Memprediksi Risiko Kebangkrutan Perusahaan (Studi kasus pada Industri Perbankan di BEI). Jurnal Ekonomi. 18(2)

Hery. 2012. Analisis Laporan Keuangan, Jakarta: Bumi Aksara.

Hidayat, M. A. dan Wahyu M. 2014. Prediksi Financial distress Perusahaan 
Manufaktur di Indonesia. Journal of Accounting. 3(3).

Husnan, Suad dan Enny Pudjiastuti. 2006. Dasar-Dasar Manajemen Keuangan. Yogyakarta: UPP STIM YKPN.

Kasmir. 2011. Analisis Laporan Keuangan. Jakarta: PT. Raja Grafindo Persada. 2014. Analisis Laporan Keuangan. Edisi Pertama. Cetakan Ketujuh. Jakarta: PT. Rajagrafindo Persada.

2015. Analisis Laporan Keuangan. Edisi Pertama. Cetakan Kedelapan. Jakarta: PT. Raja Grafindo Persada.

2016. Analisis Laporan Keuangan. Jakarta: Raja Grafindo Persada.

Laksmita, Nadia dan A. R. Komala. 2014. Analisis Laporan Keuangan. Cetakan Ketiga. Yokyakarta: UPP STIM YKPN.

Maith, H.A. 2013. Analisis Laporan Keuangan dalam Mengukur Kinerja Keuangan pada PT. Hanjaya Mandala Sampoerna Tbk. Jurnal Riset Akuntansi. 1(3).

Muflihah, I. Z. 2017. Analisis Financial distress Perusahaan Manufaktur di Indonesia dengan Regresi Logistik. Majalah Ekonomi: Telaah Manajemen, Akuntansi, Bisnis, Perbankan. 22.

Murni, M. 2018. Analisis Faktor-Faktor yang Mempengaruhi Tingkat Financial distress pada Perusahaan Manufaktur yang Terdaftar di BEI Tahun 20102014. Jurnal Akuntansi dan Bisnis. 4.

Nariman, Augustpaosa. 2016. Analisis Prediksi Kebangkrutan dan Harga Saham pada Perusahaan Pertambangan Batu Bara. JRAK. 12(2).

Platt, H dan M. Platt. 2002. Predicting Corporate Financial distress: Reflections on Choice Based Sample Bias. Journal of Economics and Finance. 26(2): 184199

Putri, N. W. K. A dan Ni Kt. Lely A. M. 2014. Pengaruh Mekanisme Corporate Governance, Likuiditas, Leverage, dan
Ukuran Perusahaan pada Financial distress. E-Jurnal Akuntansi. 7(1): 93106.

Rahayu dan Putri. 2016. Analisis penggunaan metode springate (S-SCORE) Sebagai prediktor kebangkrutan (Studi pada Perusahaa Textile yan g Terdaftar di Bursa Efek Indonesia pada Tahun 2011-2013. Jurnal Ekonomi. 1(1): 55-68.

Ratna, I. dan Marwati. 2018. Analisis FaktorFaktor yang Mempengaruhi Kondisi Financial distress pada Perusahaan yang Delisting dari Jakarta Islamic Index Tahun 2012-2016. Jurnal Tabannu: Islamic Banking and Finance. 1(1).

Real Estate Indonesia. 2015. Eureka Group Gencar Adakan Pameran Properti. http://www.rei.or.id/newrei/beritaeureka-group-gencar-adakanpameranproperti.html [Diakses pada 4 Oktober 2018].

Ross, S. A., R. W. Wasterfield, dan Jaffe, J. 2008. Corporate Finance. Edisi Kedelapan. New York: McGraw-Hill Irwin.

Saham OK. 2018. Saham delisting Sub-Sektor Real estate danproperti. https://www.sahamok.com/emiten/sekt or-properti-real-estate/subsektorproperti-realestate/] [Diakses pada 13 Oktober 2018].

Santoso, B. 2005. Prospek Kredit Properti 2005. Economic Review Journal. No.199.

Siska, N., Restu A. dan Yessi M. B. 2014. Pengaruh Rasio Likuiditas, Rasio Profitabilitas dan Rasio Pasar terhadap Return Saham pada Perusahaan yang Tergabung dalam Indeks LQ 45 di Bursa Efek Indonesia. Jurnal Online Mahasiswa. 1(2).

Sugiyono. 2012. Metode Penelitian Kuantitatif Kualitatif dan RdanB. Edisi Kelima. Bandung: Alfabeta.

Suharli, Michell. 2009. Pelaporan Keuangan Sesuai dengan Prinsip Akuntansi. Jakarta: Grasindo. 
Vitarianjani, N. 2015. Prediksi Kondisi

Financial distress dan Faktor yang Mempengaruhi Studi Empiris pada Perusahaan Batubara yang Terdaftar di Bursa Efek Indonesia Tahun 20112014. Artikel Ilmiah Mahasiswa UNEJ.

Warsono. 2003. Manajemen Keuangan Perusahaan. Malang: Bayumedia Publishing.

Wild, John J., Subramanyam, K. R., dan Halsey, Robert F. 2005. Analisis Laporan Keuangan. Edisi 8 Buku 2. Penerjemah:

Bachtiar dan Harahap. Jakarta: Salemba Empat. 